Visions of Sovereignty 
NATIONAL AND ETHNIC CONFLICT

IN THE TWENTY-FIRST CENTURY

Brendan O'Leary, Series Editor 


\section{Visions of Sovereignty}

Nationalism and Accommodation in Multinational Democracies

\section{Jaime Lluch}

\section{$\overline{\text { PENN }}$}

UNIVERSITY OF PENNSYLVANIA PRESS

PHILADELPHIA 
Copyright () 2014 University of Pennsylvania Press

All rights reserved. Except for brief quotations used for purposes of review or scholarly citation, none of this book may be reproduced in any form by any means without written permission from the publisher.

Published by

University of Pennsylvania Press

Philadelphia, Pennsylvania 19104-4112

www.upenn.edu/pennpress

Printed in the United States of America on acid-free paper

10988766543251

Library of Congress Cataloging-in-Publication Data

Lluch, Jaime.

Visions of sovereignty : nationalism and accommodation in multinational democracies / Jaime Lluch. - 1st ed.

p. cm. - (National and ethnic conflict in the twenty-first century)

Includes bibliographical references and index.

ISBN 978-0-8122-4600-1 (hardcover : alk. paper)

1. Sovereignty. 2. Separatist movements. 3. Multinational states. 4. Nationalism.

I. Title. II. Series: National and ethnic conflict in the twenty-first century.

JC327.L584 2014

$320.54-\mathrm{dc} 23$ 
Para Isabel, Jaimito, y Jaume con muchísimo amor y cariño.

Para Mami y Papi, y Rober, con mucho agradecimiento por todo el apoyo. 
